\title{
Assessing the effect of phosphorus application on early growth of maize at Sunderbazar, Lamjung, Nepal
}

\author{
Ram Kumar Shrestha*, Lal Prasad Amgain, and Sadikshya Aryal \\ Institute of Agriculture and Animal Science, Lamjung Campus, \\ Tribhuvan University, Nepal \\ *Corresponding author email: shresthark_2004@yahoo.com
}

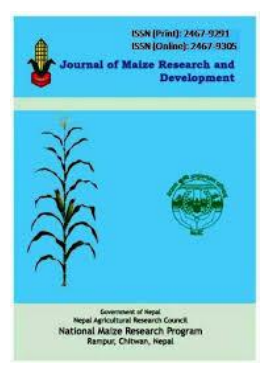

Received: September 2016; Revised: October 2016; Accepted: November 2016

\begin{abstract}
Phosphorus $(\mathrm{P})$ is an essential nutrient element for maize production. A pot experiment was conducted during May-June, 2015 to assess the effects of different rates of P on early growth of maize plant at Sundarbazar, Lamjung. Two maize varieties (Rato Makai and Poshilo Makai-1) were subjected to four P levels $\left(0 \mathrm{~kg} \mathrm{ha}^{-1}, 13 \mathrm{~kg} \mathrm{ha}^{-1}, 18 \mathrm{~kg} \mathrm{ha}^{-1}\right.$, and $\left.23 \mathrm{~kg} \mathrm{ha}^{-1}\right)$ in randomized complete block design with four replications. The effects of different $\mathrm{P}$ level on root elongation, root biomass, plant height, root shoot biomass ratio and total dry matter were investigated at 45 days after sowing. For all parameters, the maximum value was obtained when soil was added with $18 \mathrm{~kg} \mathrm{Pha}^{-1} \&$ the minimum value under the control of $0 \mathrm{~kg} \mathrm{P} \mathrm{ha}^{-1}$. Maize varieties differed significantly in terms of all the parameters under study, and Poshilo Makai-1 performed better than Rato Makai at all P levels. So, from this result, it can be concluded that Poshilo Makai-1 appeared to be $\mathrm{P}$ efficient over Rato Makai at early growth stage. However, it would be necessary to look at the response of crop up to maturity and at wider range of $\mathrm{P}$ to have the better insight of their relative performance.
\end{abstract}

Key words: Early vegetative growth, phosphorus fertilizer, maize, root shoot ratio

Correct citation: Shrestha, R.K., Amgain, L.P., \& Aryal, S. (2016). Assessing the effect of phosphorus application on early growth of maize at Sunderbazar, Lamjung, Nepal. Journal of Maize Research and Development, 2 (1), 117-122, doi:

http://dx.doi.org/10.3126/jmrd.v2i1.16222

\section{INTRODUCTION}

Maize (Zea mays L.) is one of the most important staple food crops after rice and contributes $23 \%$ of the total cereal production in Nepal (Regmi, 2011). It occupies nearly 1 million ha with an average productivity of $2.32 \mathrm{t} \mathrm{ha}^{-1}$ (KC et al., 2015). Being a constituent of cell constituents, Phosphorus (P) plays an important role in several plant processes such as photosynthesis, respiration, energy storage and transfer, cell division, and cell enlargement etc. Maize requires $\mathrm{P}$ for the higher crop yield (Chen et al., 1994). Adequate level of P not only enhances the early root formation and growth (Hajabbasi and Schumacher, 1994) but also enhances crop quality, and is needed for seed formation (IPNI, 1999; Mohan et al., 2015). P deficiency is considered to be one of the most frequently occurring limitations in the productivity 
of crops grown in tropical and subtropical ecological regions (Ramaekers et al., 2010) where P can strongly fixed to the soil through adsorption and precipitation thereby reducing its bioavailability to the plants (DoVale \& Fritsche-Net, 2013). Being an important constituent of organic compounds in the plants, P deficiency reduces plant growth (Marschner, 1977). Low concentration of soil available $\mathrm{P}$ is one of the major constraints to sustain optimal crop production (Wang et al., 2011) and its availability is very important during the early growth stage (Alley, 2009). Absence of the P fertilizer application, especially in the intensive cultivation systems, result in low soil P content (Smaling et al., 1997). Since majority of the Nepalese soils are low in soil available P (Dawadi \& Thapa, 2015), P could be limiting factor for the Maize production, especially in the hilly regions of Nepal. The yield of maize, thus, could be increased by the application of soil application of $\mathrm{P}$ fertilizer. Existing fertilizer recommendations including $\mathrm{P}$ fertilizer- by government bodies consist of fixed rates without considering the sitespecific soil and weather condition. Thus, it is hypothesized that addition of $\mathrm{P}$ in the soil would improves the yield attributing parameters of the maize, and its requirement varies with the maize varieties. The objective of this research was to assess the effect of different level of $\mathrm{P}$ fertilizer on the early growth of two maize varieties and to screen the P- efficient variety.

\section{MATERIALS AND METHODS}

A pot experiment was conducted under diffused light condition in the farm of Lamjung Campus, Sundarbazar, Lamjung (700 masl), Nepal during May-June, 2015. Average daily mean temperature and precipitation during that period were recorded as $17.32^{\circ} \mathrm{C}$ and $3.19 \mathrm{~mm}$. The experiment included two factors- maize varieties and P levels. Soil was collected from maize field, Lamjung Campus; air dried for 48 hours and filled in poly-pots $(5 \mathrm{~L})$ at the rate of $3 \mathrm{~kg} \mathrm{pot}^{-}$ ${ }^{1}$. Then soil was treated with nitrogen $(\mathrm{N})\left(40 \mathrm{~kg} \mathrm{ha}^{-1}\right)$, potassium $(\mathrm{K})\left(17 \mathrm{~kg} \mathrm{ha}^{-1}\right)$ and other nutrients including magnesium $(\mathrm{Mg})$, cupper $(\mathrm{Cu})$, manganese $(\mathrm{Mn})$, calcium $(\mathrm{Ca})$, molybdenum (Mo), zinc (Zn), boron (B) and iron (Fe) (30, 2, 0.2, 71, 0.2, 1, $1 \& 2 \mathrm{ppm}$ respectively). For treatment application, soil was treated with four $\mathrm{P}$ levels $\left(0 \mathrm{~kg} \mathrm{ha}^{-1}, 13 \mathrm{~kg} \mathrm{ha}^{-1}, 18 \mathrm{~kg} \mathrm{ha}^{-1}\right.$, and 23 $\left.\mathrm{kg} \mathrm{ha}{ }^{-1}\right)$ through sodium phosphate $\left(\mathrm{NaH}_{2} \mathrm{PO}_{4}\right)$. In each pot, three pre-germinated seeds of maize varieties [Rato Makai (a local variety) and Poshilo Makai-1(an improved variety)] were sown at $5 \mathrm{~cm}$ depth. Those eight treatments were arranged in randomized complete block design with four replications. Seven days after sowing (DAS), only one seedling per pot was left. Water lost due to evapotranspiration was replaced at every alternative day and maintained at pot's maximum water holding capacity against gravity (field capacity). Before harvesting the plants at 45 DAS, plant height was measured. Root and shoot were separated, washed with water and root length was measured. This was followed by oven drying of roots and shoots at $60^{\circ} \mathrm{C}$ for 72 hours. Oven dried roots and shoots were then weighed. Data were subjected to the ANOVA using SPSS Windows Version 20 and treatment means were separated using Tukey's test to signify the treatments difference at $5 \%$ of probability.

\section{Effect on root length}

\section{RESULTS AND DISCUSSION}

The mean values of the root length, root dry matter and plant height for maize varieties and P levels are presented in Table 1. When added to the soil, P showed significant effect on root length in maize varieties under study. Irrespective of the maize varieties, length of root was 
highest when they were grown at $18 \mathrm{~kg} \mathrm{P} \mathrm{ha}^{-1}$ (Table 1). This might be due to the $\mathrm{P}$ stimulated utilization of assimilates in root system thereby enhancing root length. Root length at $23 \mathrm{~kg} \mathrm{P}$ $\mathrm{ha}^{-1}$ did not significantly differ than at $18 \mathrm{~kg} \mathrm{P} \mathrm{ha}^{-1}$. Poshilo Makai-1 again expressed longer roots than the Rato Makai when no $\mathrm{P}$ was applied. The observed effect of P application on root elongation is consistent with the results of Hajabbasi and Schumacher (1994) and Rosoem et al. (1994), but disagrees the finding of Anuradha and Narayanan (1991).

\section{Effect on root biomass}

Initially, increase in level of $\mathrm{P}$ appeared to be positively correlated with root biomass. Maize varieties produced least biomass when no $\mathrm{P}$ was applied, and highest value was obtained at $18 \mathrm{~kg} \mathrm{P} \mathrm{ha}{ }^{-1}$. Application of $\mathrm{P}$ enhances root elongation and in turn increases root biomass. Amijee et al. (1989) stated that $\mathrm{P}$ inflow have direct effect in root weight which in turn increases density of root branching. These effects lead to increase $\mathrm{P}$ acquisition as well as other nutrients. This is the reason that plant grown under control of no $\mathrm{P}$ application accumulated least root biomass. The root weight, however, was found to be greater in Poshilo Makai-1 than that of Rato Makai.

\section{Effect on plant height}

Different level of applied $\mathrm{P}$ showed significant effect on plant height (Table 1). Plant height was least at $0 \mathrm{~kg} \mathrm{P} \mathrm{ha}^{-1}$ and the highest value was recorded at $18 \mathrm{~kg} \mathrm{P} \mathrm{ha}^{-1}$, followed by $\mathrm{P}$ at the rate of $23 \mathrm{~kg} \mathrm{ha}^{-1}$. This result reveals that $\mathrm{P}$ at the rate of $18 \mathrm{~kg} \mathrm{ha}^{-1}$ might be the optimum rate for the maize and could trigger plant growth. Amin et al. (1989) also observed similar effects of $\mathrm{P}$ on plant height in maize. $\mathrm{P}$ induced plant growth is strongly associated with the better root growth and nutrient uptake (Hussain et al., 2006). Babatola et al. (2002) also observed the positive effect of $\mathrm{P}$ on plant growth. Decreased plant height at $23 \mathrm{~kg} \mathrm{P} \mathrm{ha}^{-1}$ may be due to the antagonistic effect of high soil $\mathrm{P}$ on uptake and assimilation of other elements that would have positive role on plant growth (Uguru, 1996). At control treatment, plant height was greater for Poshilo Makai-1 than that of Rato Makai, and could be related to the genetic effect. This result, however, is in contrary to the finding of Eltelib et al. (2006) who reported that plant height of the maize decreased at increasing $\mathrm{P}$ levels.

Table 1. Plant height, root length and root biomass of maize varieties as affected by added $P$ in soil

\begin{tabular}{|c|c|c|c|c|c|c|}
\hline \multirow{3}{*}{$\begin{array}{l}\text { P Level } \\
\left(\mathrm{kg} \mathrm{ha}^{-1}\right)\end{array}$} & \multicolumn{2}{|c|}{ Root length $(\mathrm{cm})$} & \multicolumn{2}{|c|}{ Root biomass (g) } & \multicolumn{2}{|c|}{ Plant height $(\mathrm{cm})$} \\
\hline & Rato & Poshilo & Rato & Poshilo & Rato & Poshilo \\
\hline & Makai & Makai-1 & Makai & Makai-1 & Makai & Makai-1 \\
\hline 0 & $13.12^{\mathrm{d}}$ & $19.17^{\mathrm{c}}$ & $0.165^{\mathrm{c}}$ & $0.20^{\mathrm{c}}$ & $57.20^{b}$ & $62.42^{b}$ \\
\hline 13 & $20.55^{\mathrm{c}}$ & $29.32^{b}$ & $0.34^{\mathrm{b}}$ & $0.40^{\mathrm{b}}$ & $58.00^{\mathrm{b}}$ & $65.60^{\mathrm{b}}$ \\
\hline 18 & $50.82^{\mathrm{a}}$ & $62.02^{a}$ & $0.47^{\mathrm{a}}$ & $0.53^{\mathrm{a}}$ & $73.72^{a}$ & $78.85^{\mathrm{a}}$ \\
\hline 23 & $44.37^{\mathrm{b}}$ & $57.57^{\mathrm{a}}$ & $0.42^{\mathrm{ab}}$ & $0.46^{\mathrm{ab}}$ & $66.7^{\mathrm{ab}}$ & $71.00^{\mathrm{ab}}$ \\
\hline
\end{tabular}

Mean values followed by the same lowercase letter in the column are not significantly different by Tukey test $(\alpha=0.05 ; n=4)$ 


\section{Effect on root shoot ratio}

Different level of $\mathrm{P}$ showed significant effect on root shoot ratio (Fig 1). Addition of $\mathrm{P}$ was positively correlated with root shoot ratio up to a certain P level, and above that, negative effect on root shoot ratio was observed. While the lowest root shoot ratio (0.5) was observed at control of no $\mathrm{P}$ application, the highest value was at $18 \mathrm{~kg} \mathrm{P}^{-1}$ (1.6). When no $\mathrm{P}$ was applied, root shoot ratio was found to be higher for Poshilo Makai-1 (0.5) than that for Rato Makai (0.4). $\mathrm{P}$ induced higher root biomass relative to that of shoot biomass in the maize plant might be due to the roles of $\mathrm{P}$ on root growth at early vegetative stage. The opposite effect, however, can be expected at later stage of plant growth and at higher P application. Reduction of root shoot ratio is also associated with higher level of $\mathrm{P}$ in growing medium (Wilson \& Haydock, 1971). On contrast, P- induced lower root shoot ratio have also been reported (Rychter \& Randall, 1994; Ciereszko et al., 1996) and was associated with the partitioning of higher proportion of photosynthetes to the above ground plant part. According to Gregory and Richards (1929) plants grown at low soil $\mathrm{P}$ tend to produce a higher photosynthetic rate. This higher photosynthetic rate causes increased leaf biomass. Hence, root shoot ratio is lower.

\section{Effect on dry matter}

Soil application of $\mathrm{P}$ significantly increased the total biomass yield as compared to the control of no P application; but only up to a level. Maize plants accumulated the least dry matter $(0.5 \mathrm{~g})$ when no $\mathrm{P}$ is applied, while this value reached to $0.8 \mathrm{~g}$ at $18 \mathrm{~kg} \mathrm{Pha}^{-1}$, and this value did not differ significantly when grown at $13 \mathrm{~kg} \mathrm{P} \mathrm{ha}^{-1}(0.73 \mathrm{~g}) \& 23 \mathrm{~kg} \mathrm{Pha}^{-1}(0.75 \mathrm{~g})$. Irrespective of the P level, Poshilo Makai-1 produced higher biomass $(0.74 \mathrm{~g})$ than Rato Makai $(0.68 \mathrm{~g})$. This may be attributed to the role of $\mathrm{P}$ for the cell division at meristematic tissue and other physiological activities (Russel, 1973). Pellerin et al. (2000) have reported that the soil applied P induced dry matter yield is associated with improvement of root system, increased leaf area index and, in turn, its positive effect on photosynthesis and carbohydrate nutrition of plant. The higher P level $\left(23 \mathrm{~kg} \mathrm{P} \mathrm{ha}^{-1}\right)$ did not result in increase in dry matter production. This may be due to the Fe accumulation in the roots under higher soil P level (Holmes, 1960).

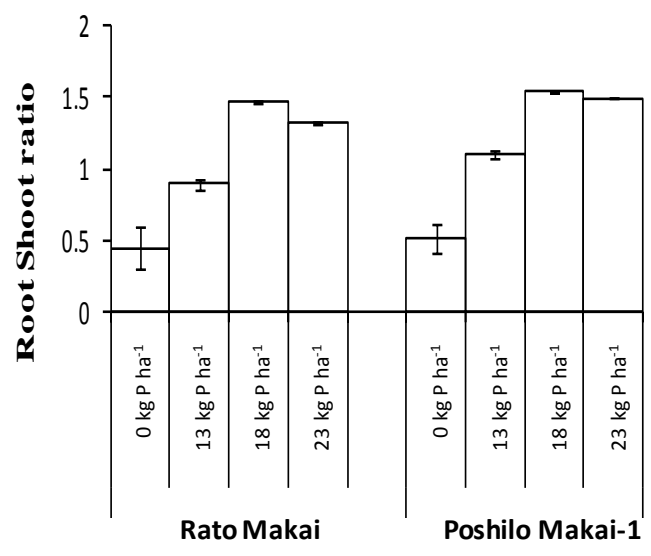

Figure 1. Effect of additional level of $P$ in soil on root shoot ratio at 45 DAS in maize varieties.

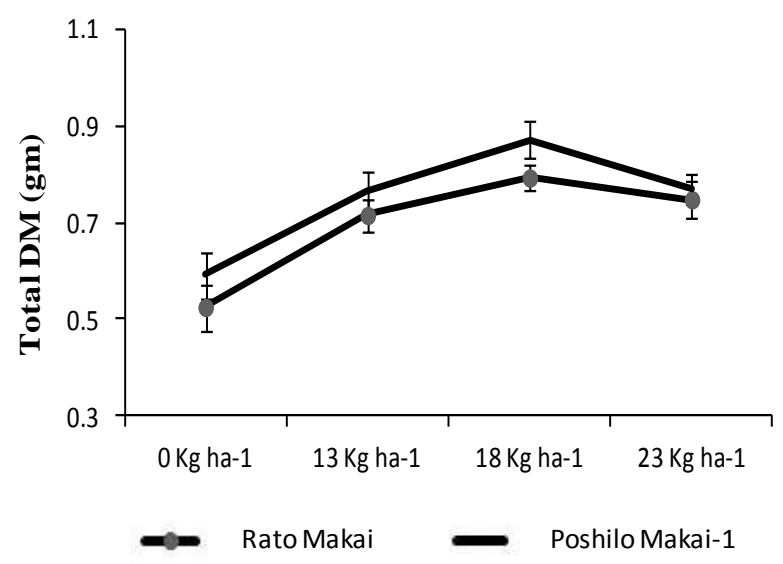

Figure 2. Effect of additional level of $P$ in soil on total dry matter at 45 DAS in maize varieties. 


\section{CONCLUSION}

The findings of this experiment have revealed that application of $\mathrm{P}$ to the soil significantly affects maize growth. At early growth stage, increasing concentration of $\mathrm{P}$ to certain level increases root length, root biomass, plant height and root shoot ratio and total dry matter, and $18 \mathrm{~kg} \mathrm{P} \mathrm{ha}^{-1}$ appear to be optimum in context of Lamjung, Nepal. Plant showed relatively poor growth if $\mathrm{P}$ is not applied to the soil. Poshilo Makai-1 (improved variety) performs better over Rato Makai (local variety) even for same level of soil $\mathrm{P}$ including control of no $\mathrm{P}$ application. These conclusions can only be preliminary and further studies need to compare the $\mathrm{P}$ response of different genotypes at field condition as well as to the maturity level.

\section{ACKNOWLEDGEMENTS}

Authors offer their sincere appreciation to Dr. Basu Dev Regmi for his technical support to conduct this study.

\section{REFERENCES}

Alley, M.M. (2009). Nitrogen and phosphorous fertilization of Corn. Retrieved from https://pubs.ext.vt.edu/424/424-027/424-027.html.

Amin, R., Zia, M.S., Berger, K.C., \& Aqil, K. (1989). Effect of fertilizer rate and phosphorus placement methods on corn production. Sarhad Journal of Agriculture, 5, 221-227.

Anuradha, M., \& Narayanan, A. (1991). Promotion of root elongation by phosphorus deficiency. Plant and Soil, 136(2), 273-275.

Babatola, L. A. (2013). Effects of NPK 15:15:15 fertilizer on the performance and storage life of okra (Abelmuschus esculentus). Journal of Agriculture, Biotechnology and Ecology, 6(1), 95-101.

Chen, M.L., Jiang, X.L., Zoov, B.Y., \& Zheri, Z.Y.(1994). Mathematical models and best combination of high yield cultivation technique for rapeseed variety Zhenyouyoum Acta Agric Zhejiiangenesis, 6, 22-26.

Dawadi, D.P., \& Thapa, M. (2015). Soil fertility status of Nepal: Report from laboratory analysis of soil samples of five Developmental Regions. In: Proceedings of the Second National Soil Fertility Research Workshop, 24-25 March, 2015. NARC. pp.42-52.

DoVale, J. C., \& Fritsche-Net, R. (2013). Genetic control of traits associated with phosphorus use efficiency in maize by REML/BLUP. Revista Ciência Agronômica, 44(3), 554-563.

Eltelib, H.A., Hamand, M.A., \& Ali, E.E. (2006). The effect of nitrogen and phosphorus fertilization on growth, yield and quality of forage maize (Zea mays L.). Journal of Agronomy, 5, 515-518.

Gregory, F.G., \& Richards, F. J. (1929). Physiological studies in plant nutrition (I) The effect of manorial deficiency on the respiration and assimilation rate in barley. Annuals of Botany, 43, 119-61.

Hajabbasi, M.A, \& Schumacher, T. E. (1994). Phosphorus effects on references root growth and development in two maize genotypes. Plant and Soil, 158, 39-46. 
Holmes, R. S. (1960). Effect of phosphorus and pH on iron chlorosis of the blueberry in water culture. Soil Science, 90(6), 374-379.

Hussain, N., Khan, A.Z., Akbar, H., \& Akhtar, S. (2006). Growth factors and yield of maize as influenced by phosphorus and potash fertilization. Sarhad Journal of Agriculture, 22(4), 579-583.

IPNI (1999) Phosphorus Improves Crop Quality. Better Crops, 83, 28-29

KC, G., Karki, T.B., Shrestha, J., \& Achhami, B.B. (2015). Status and prospects of maize research in Nepal. Journal of Maize Research and Development (2015), 1(1), 1-9.

Marschner, H. (1997). Mineral nutrition of higher plants. $2^{\text {nd }}$ Edition. London: Academic Press. Hacourt Brace and Company, London.

Mohan, S., Singh, M., \& Kumar, R. (2015). Effect of nitrogen, phosphorus and zinc fertilization on yield and quality of kharif fodder- A review. Agricultural Reviews, 36 (3), 218-226.

Pellerin, S., Mollier, A., \& Plénet, D. (2000). Phosphorus deficiency affects the rate of emergence and number of maize adventitious nodal roots. Agronomy Journal, 92, 690697.

Ramaekers L., Remans, R., Rao, I. M., \& Vanderleyden, J. (2010). Strategies for improving phosphorus acquisition efficiency of crop plants. Field Crops Research, 117(2-3), 169176.

Regmi, P. (2011). Ensuring food security and securing livelihoods in Nepal: A road map in the Context of Climate Change and Adaptation" (Retrieved from http://www.mope.gov.np/download/Ensuring\%20Food\%20Security\%20and\%20Securing $\%$ 20Livelihoods\%20in\%20Nepal\%20Context\%20of\%20CC\%20and\%20Adaptation.doc x.6d0f2f40aea4e868d7b84dabff2f2f77).

Rosolem, C.A., Assis, J.S., \& Santiago, A. D. (1994). Root growth and mineral nutrition of corn hybrids as affected by phosphorus and lime. Communications in Soil Science and Plant Analysis shoot, 25, 2491-2499.

Russell, E.W. (1973). Soil Condition and Plant Growth. The English Language Book Society and Longman, London.

Smaling, E. M. A., Nandwa, S. M., \& Janssen, B. H. (1997). Soil fertility is at stake. In: Replenishing soil fertility in Africa. Soil Science Society of America Special Publication 51, 47-61

Uguru, M.I. (1996). Crop production techniques. (Revised ed.) Fulladu Publication Co. Nsukka.

Wang, T., Camps-Arbestain, M., Hedley, M., \& Bishop, P. (2012). Predicting phosphorus bioavailability from high-ash biochars. Plant and Soil, 357(1-2), 173-187.

Wilson, J. R., \& Haydock, K. P (1971). The comparative response of tropical and temperate grasses to varying levels of nitrogen and phosphorus nutrition. Australian Journal of Agricultural Research, 22, 573-87. 